\title{
Semantic Relativism and Information Science: An Exploration of District of Columbia v. Heller (2008)
}

\section{By: Elizabeth Zak, University of Iowa}

\begin{abstract}
Semantic relativism supplies an underutilized method to analyze the information a statement presents by signaling the context of judgement. This study applies semantic relativism to the Supreme Court of the United States case District of Columbia v. Heller (2008) to understand the differing legal opinions released by the Court. While information literacy focuses on bias in sources, semantic relativism allows us to evaluate the information presented. Since it attends to the context of judgement, semantic relativism can be utilized with other information science tools that evaluate the legitimacy of information interpretation.
\end{abstract}

Keyword(s): information science, semantic relativism, context of judgement Introduction

In the age of misinformation, when we are presented with polarizing opinions, it is typically the case that one opinion is framed as dominant and truthful while the other opinion is marginalized or minoritized. Similarly, echo chambers can result in a lack of exposure to any outside information or contrary arguments. In a broader, philosophical sense, ignoring differing opinions is defined as an example of doxastic voluntarism. Doxastic voluntarism is defined as the belief that people may choose whether or not to believe an outside opinion. Relativistic thinking can enable us to view subjective information from an objective standpoint. According to the Stanford Dictionary of Philosophy, relativism states that "at least some class of things have the properties they have...only relative to a given framework of assessment... and correspondingly, that the truth of claims attributing these properties holds only once the relevant framework of assessment is specified or supplied" (Baghramian). In short, this means that the 
understanding of a concept is inherently based on the presentation of the concept. Some argue that there is no true objectivity: semantic relativism allows us to evaluate arguments freely of this notion. Although there is no true objective viewpoint, semantic relativism focuses on difference in synthesis of information. Semantic relativism is a term that focuses on the determination of the concept's meaning: what is true or false is based on the context of judgement of the person who presents the information. Semantic relativism requires that we analyze more than one opinion: it invites us to view others. This paper begins with a brief literature review of semantic relativism. Since a court case allows us to view both the majority and minority opinions, it is a strong test for the capacity of semantic relativism to analyze both the information presented and each side's interpretation of the information. I introduce the term context of judgement which allows us to understand each argument from a semantic relativist perspective. Since this analysis highlights the context of judgement, it indicates the potential for semantic relativism in information science.

\section{Definition of Terminology}

A discussion of any Supreme Court case begins with an understanding of its terminology. Semantic originalism, coined by Robert Dworkin, is the belief that the original meaning as understood by the general public of a text is its current meaning, regardless of any changes or nuances in current time (Goldsworthy, 2000). When discussing semantic originalism, McMurray explains that "the problem lies in the fact that there are multiple, competing viable theories of language" (McMurray, 2019). McMurray also states that "although semantic theories all share a common purpose, they do not necessarily agree in every respect" (McMurray, 2019). McMurray focuses on semantic originalism in the legal field, arguing that "to discover what the Constitution means, we must look to its original public meaning" (McMurray, 2019). Public meaning is defined as "conventional semantic meaning of a constitutional provision as understood by 
ordinary but competent speakers at the time of its framing” (McMurray, 2019). Specifically, the author's intended meaning is eschewed in favor of how it is perceived. In other words, historical context is essential to understanding the Constitution's meaning.

Contextualism and originalism are two ways to understand the Supreme Court. Contextualism originated in the 1950 s and is defined as "knowledge attribution...depends partly on something in the context of the attributor" (Rysiew, 2020). In the case of opinions, someone's experiences may result in one preference over another. A contextualist Supreme Court justice, such as Stephen Breyer, "believes the Court should look at the purpose as opposed to the text of the constitutional clause or statute under review" (Urofsky, 2002). Similarly, originalism was initially developed in the 1980 s as a term and is defined as the belief that "that the constitutional text ought to be given the original public meaning that it would have had at the time that it became law" (Calabresi, Beeman, Rubenstein, \& Siegel). Solum comments on the difficulty in defining originalism, stating that "Undoubtedly, we can find many other explicit or implicit definitions of "originalism," but it seems clear that no single definition commands the assent of constitutional scholars" (Solum, 2019). In the case of the Supreme Court, originalists may not only focus on the original meaning of the constitutional text, but legal precedent (Solum, 2019).

MacFarlane defines semantic relativism, claiming that "truth depends not only on how things are with the objects they explicitly concern, but on how things are with some subject not explicitly mentioned" (Macfarlane, 2007). In other words, semantic relativism allows us to understand the validity of two contradicting statements by examining their context.

This set of definitions can allow us to further explore the legal system and especially the case of District of Columbia v. Heller (2008). Rather than focusing on a legal or rhetorical aspect, I chose to focus semantic relativism in information theory. Although we are examining a 
court case, we are choosing to read it through an information science lens, focusing on each interpretation of the information presented in order to explore the context of judgement in each opinion. Since this research focuses on the difference in interpretation of information, it fits neatly under the information science discipline.

\section{Semantic Relativism in Information Theory}

Semantic relativism is relatively underexplored when discussing information theory. Advocates both define and recommend semantic relativism's use in information science. Brodie is one of the first to define semantic relativism, in 1984. Brodie argues that semantic relativism "concerns the ability to view and manipulate data in the way most appropriate for the user" (Brodie, 1984). This means that the perception of information depends on the presentation method used by the person presenting the information and any manipulation they may perform. Brodie defends semantic relativism, stating that it "permits differing views to coexist and evolve" (Brodie, 1984). In 2018, Berskyte writes that "semantic relativism maintains that the truth-value of some propositions is sensitive to a judge parameter, facilitating cases whereby a proposition can be true relative to one judge, but false relative to another" (Berskyte, 2018). Although some may argue that relativism destroys truth as a concept, Baghramian argues that propositions are "true only relative to a context of assessment that includes a body of knowledge" (Baghramian). Specifically, Baghramian explains the benefits of semantic relativism, explaining its use as "a harbinger of tolerance and the only ethical and epistemic stance worthy of the open-minded and tolerant" (Baghramian). This well-used definition of semantic relativism supplies a useful idea: the context of judgement. Context of judgement is what someone observing and evaluating information chooses to focus on something as they understand it before then presenting it to others. A person's context of judgement is here defined 
as the set of facts they choose to discuss and analyze when evaluating an argument. Because people have different criteria, concept of judgement allows drastically different syntheses from the same piece of information. Specifically, context of judgement can identify how people evaluate and then present information. Understanding the context of judgement allows us to analyze an argument's validity.

Critics of semantic relativism decry its specificity and limitations. Tarasov explains that semantic relativism is "a view that raises more philosophical questions than relativists and nonrelativists alike have accounted for" (Tarasov, 2020). In 2007, Glanzberg argued that a lack of relativism in language over-generalizes arguments. Glanzberg writes that "for many evaluative adjectives, it is not so clear if we have well-defined averages" (Glanzberg, 2007). When applying semantic relativism to a sentence that contains any gradable adjective, such as tall or pretty, there is no absolute truth. Beauty is in the eye of the beholder and tall is a relative adjective. Glanzberg argues that by focusing on the context of an argument, we can determine where any alternative perspectives may lie. According to Glanzberg, contextualism is superior to semantic relativism when analyzing statements of personal taste. Semantic relativism is insufficient; understanding the speaker's mindset is more important. Similarly, Marques explains that "there's no answer as to whether the aim of speaking truly is ever achieved. At best, speakers can aim to speak truly from a context" (Marques, 2019). Marques states that while semantic relativism is appealing, it is limited to statements that will always be truthful.

Both Glanzberg and Marques offer helpful insights. Their critiques show that semantic relativism has its limits; however, in many cases, semantic relativism should be used as a primary form of evaluation. Glanzberg explains that contextualism is better than semantic relativism when analyzing someone's personal taste. However, when analyzing a case of 
objective truth, semantic relativism is the only proper methodology because it does not focus on the speaker's personal context. When Marques explains that semantic relativism is limited, this does not mean that semantic relativism is useless. Semantic relativism is imperfect when analyzing personal taste and ambiguous statements. Despite its limitations, semantic relativism is still useful for analysis. Semantic relativism accounts for the context of the judgement rather than the context of the speaker.

To understand context of judgement, we shall use this example. Three people are approached on the street and handed a pamphlet about Seattle detailing its tech, its school system, its urbanity, and its bustling arts scene. They are then asked to answer the question: "Is Seattle the best city?" Person A responds in the affirmative, stating that Seattle is the best city because of its school system. Person B responds in the negative, stating that Seattle is far too urban. Person $\mathrm{C}$ responds in the affirmative, stating that Seattle is the best city because of its art scene.

Each person chooses different things to focus on when presented with the same information. Specifically, although Person A and Person C agree that Seattle is the best city, they have two different reasons. Although personal preference certainly plays a role in understanding this information and focus, there is also factual evidence to back up their claims. Each person has a valid context of judgement because they base their decision on both the text and their specific selection criteria rather than their own personal experience with Seattle. Once personal experience and opinion are removed, the context of judgement remains. For example, arguing that Seattle is a bad city because of its high crime rate would be an invalid context of judgement. Although it may be factually true, it was not provided in the pamphlet and provided information given. 


\section{Methodology}

The case chosen, District of Columbia v. Heller (2008), focuses intentionally on a stagnant text and on the views of the judgment to demonstrate that contextualism can serve as a complement to semantic relativism. District of Columbia V. Heller (2008) also focuses on the language and phrasing of the Second Amendment, as well as the historical context and other laws written during that time. Unlike other Supreme Court cases, the two arguments discussed from this court case center on the linguistic nature of the Second Amendment, a text whose literal wording remains fixed despite differing interpretations. The two arguments analyzed are the majority opinion, written by Justice Antonin Scalia and the minority opinion, written by Justice John Paul Stevens. I have chosen to analyze Justice Scalia's majority opinion and Justice Stevens' dissent as they both present cases that are fully based on an interpretation of the Constitution. Although Justice Breyer also wrote a dissent, the dissent focuses on the handgun proper, and therefore was not analyzed. Whereas scholars have applied linguistic and semantic analysis to this case (Hobbs, 2012; McManus, 2019), I will compare the opposing opinions and their interpretations of the Second Amendment. Because these two justices present totally different arguments, I found this case relevant to semantic relativism. My intention is not to equate the two arguments; I do not want to defend or condemn either one. Similarly, I choose not to explore this from a jurisprudential perspective, as the ruling clearly positions one collective opinion above the other. Although their implications on society are important, I chose to focus on the opinions. Rather, I apply semantic relativism for the purpose of evaluating each argument on the basis of the context of judgement.

\section{District of Columbia v. Heller (2008)}

The Supreme Court Case District of Columbia v. Heller (2008) explored the following question: Do the provisions of the District of Columbia Code that restrict the licensing of 
handguns and require licensed firearms kept in the home to be kept nonfunctional violate the Second Amendment? Dick Heller was a D.C. police officer who wished to have a permit for a handgun in his own home specifically for self-defense. Although as a police officer, he was allowed to carry a handgun, he was unable to keep his own handgun. Heller had already approached the National Rifle Association to overturn the ban and was refused. The court ruled 5-4 that Heller could keep a handgun in his own home, with Scalia writing the majority opinion, Stevens writing the dissent and Breyer writing another dissent.

Each justice possesses a unique argument style, which allows for different interpretations of the law. McManus explores Justice Antonin Scalia's argument style. Scalia's legal philosophy is originalist. McManus discusses one part of the originalist thinking: plain meaning view. By defining plain meaning view as "the meaning of legal terms is a settled thing, and it is the duty of legal officials, especially judges, to simply apply that meaning to a given case in hand," McManus allows us to understand Scalia from his words (McManus, 2019). Since there must be ambiguity for a case to be brought before the Supreme Court, interpretation is necessary. Hobbs explores the District of Columbia v. Heller, focusing on Scalia's analysis of the Second Amendment. Hobbs explains that from a linguistic perspective, Scalia "literally cut the amendment in half by separating its two clauses" (Hobbs, 2012). Hobbs continues, stating that linguistic analysis is incomplete because "while linguistic analysis cannot determine the applicability of a statutory or constitutional provision, it can expose the flaws in the court's approach where linguistic rules are misused to decide a case" (Hobbs, 2012). Therefore, this linguistic analysis must be accompanied by a historical context. This allows Scalia to make an argument regarding historical analysis. When analyzing the argument from a legal standpoint, 
Hobbs says that "indeed, legal scholars have been sharply critical of Heller" (Hobbs,2012).

However, Hobbs does not compare Scalia's argument to that of his peers.

Spaak focuses on relativism in legal theories. Spaak states that there is no true definition of relativity in law and calls for more research to be done in relativist moral disagreement (Spaak, 2019). Spaak's discussion of two different theories focuses on the difference between one's interpretation in legal documents. However, Spaak does not explore any specific legal cases.

Semantic relativism requires a diversity of opinions. Evaluating a supreme court case allows us to view both opinions, which differ, that are based on interpretations of the same sentence. Both these opinions are fact based; once again, the context of judgement differs. Both judges choose to focus on two different aspects of the Second Amendment. There are limitations to applying semantic relativism to a legal case: our laws are not based on relativism; they are based on a set of rules, ideally applied equally and indiscriminately. Because the SCOTUS makes decisions by voicing both opinions, it gives us a test case for exploring the contours of semantic relativism.

\section{Second Amendment Exploration}

Applying semantic relativism to a legal case allows us to view that case through a unique lens. The Second Amendment states "A well regulated Militia, being necessary to the security of a free State, the right of the people to keep and bear Arms, shall not be infringed" (U.S. Const. amend. II). This is a statement that has been contested since its inception. Presser v. Illinois (1886) and United States v. Miller (1939) have challenged both the definition of "militia" and “arms". In Presser v. Illinois(1886), the court ruled that "There is no Second Amendment violation when a state bans private citizens from forming personal military groups, drilling, and 
parading" (Presser v. Illinois, 116 U.S. 252 (1886)). In United States v. Miller(1939), the court ruled unanimously, McReynolds writing that "because possessing a sawed-off double barrel shotgun does not have a reasonable relationship to the preservation or efficiency of a wellregulated militia, the Second Amendment does not protect the possession of such an instrument"( United States v. Miller, 307 U.S. 174 (1939)). However, in 2008's District of Columbia v. Heller, the Supreme Court ruled that handgun ownership is constitutional. Each opinion was based on the Justices' reading of the Constitution as a text; differences in interpretation were based on the Justices' particular application of semantic and historical contexts.

Utilizing an originalist argument, Justice Antonin Scalia explains that based on definitions of a militia, which is not regulated by Congress, "Although the militia consists of all able-bodied men, the federally organized militia may consist of a subset of them" (Scalia, 128 S.Ct. at 2796). Scalia also discusses the idea that due to historical context, "history showed that the way tyrants had eliminated a militia consisting of all the able-bodied men was not by banning the militia but simply by taking away the people's arms, enabling a select militia or standing army to suppress political opponents" (Scalia, 128 S.Ct. at 2796). Reading the Second Amendment in this way can therefore show the founding fathers' purpose: to prevent the government from taking away weapons. Therefore, Scalia argues, "at the time of the Second Amendment's ratification was the body of all citizens capable of military service, who would bring the sorts of lawful weapons that they possessed at home" (Scalia, 128 S.Ct. at 2796). The idea that Heller was capable of military service meant that Heller could possess his handgun. Similarly, Heller's handgun would allow him to combat a tyrannical government should this ever form in the United States. After discussing each part of the statement, Scalia states that "Putting all of these textual elements together, we find that they guarantee the individual right to possess 
and carry weapons in case of confrontation" (Scalia, 128 S.Ct. at 2796). Scalia concludes by reiterating that the Second Amendment "surely elevates above all other interests the right of lawabiding, responsible citizens to use arms in defense of hearth and home" (Scalia, 128 S.Ct. at 2796). Scalia concludes, affirming his argument by explaining that "the enshrinement of constitutional rights necessarily takes certain policy choices off the table" (Scalia, 128 S.Ct. at 2796). This decision was later used to set precedence in the later Supreme Court case, McDonald v. City of Chicago (2010). Scalia uses the historical context of the Second Amendment to argue that a weapon's self-defense purpose is necessary.

In his dissent, Justice Stevens states that the Second Amendment "does encompass the right to use weapons for certain military purposes. Whether it also protects the right to possess and use guns for nonmilitary purposes like hunting and personal self-defense is the question presented by this case" (Stevens, Dissenting, 128 S.Ct. at 2826).Once again, Stevens draws upon the literature, explaining that by detailing a militia and its necessity, "It identifies the preservation of the militia as the Amendment's purpose; it explains that the militia is necessary to the security of a free State; and it recognizes that the militia must be "well regulated" (Stevens, Dissenting, 128 S.Ct. at 2826). Stevens explains that the military is an important part of the country. However, Stevens focuses on weapons as a form of self-defense. As a result, Stevens explains that the omission of weapons used for hunting of self-defense is telling since many other states' Declarations of Rights expressly encourage these weapons. Therefore, the founding fathers understood that these distinctions existed. Stevens argues that the use of guns as self-defense tools were omitted to prioritize the military. Stevens furthers this point by explaining that the words "the people" are used to "remind us that it is the collective action of individuals having a duty to serve in the militia that the text directly protects" (Stevens, 
Dissenting, 128 S.Ct. at 2826). Stevens continues by discussing the right to bear arms, stating that " - they describe a unitary right: to possess arms if needed for military purposes and to use them in conjunction with military activities" (Stevens, Dissenting, 128 S.Ct. at 2826). Therefore, since self-defense is not discussed in the Second Amendment, a personal gun for self-defense is not protected under the Second Amendment. Stevens further argues this by explaining the definition of "bear arms" as the "the most natural meaning is the military one; and, in the absence of any qualifier, it is all the more appropriate to look to the preamble to confirm the natural meaning of the text" (Stevens, Dissenting, 128 S.Ct. at 2826). After discussing each portion of the Second Amendment, Stevens summarizes it by stating that "When each word in the text is given full effect, the Amendment is most naturally read to secure to the people a right to use and possess arms in conjunction with service in a well-regulated militia" (Stevens, Dissenting, 128 S.Ct. at 2826). Stevens also focuses again on state-level decisions about selfdefense firearms. Stevens argues explicitly that "it is clear that he[James Madison] considered and rejected formulations that would have unambiguously protected civilian uses of firearms" (Stevens, Dissenting, 128 S.Ct. at 2826). Stevens then reiterates that “- - to protect against congressional disarmament, by whatever means, of the States' militias" Stevens concludes by stating that this decision "fails to pay heed to a far more important policy choice—-the choice made by the Framers themselves" (Stevens, Dissenting, 128 S.Ct. at 2826). Stevens' dissent discusses the historical context of the Second Amendment. Further, he discusses the Second Amendment's context within similar texts of the time, utilizing a broad background.

\section{Discussion}

Applying semantic relativism to District of Columbia v. Heller (2008) illuminates the context of judgement in each opinion. The words of the Constitution have not changed: however, 
there are two very different interpretations of these words. By explaining the importance of the founding fathers' context while writing the Constitution, Scalia et al argue that guns are constitutional for self-defense purposes. Scalia's position as an originalist, or someone who argues that the constitution must be interpreted based on the understandings at the time it was adopted, allowed him to translate the intent behind the founding fathers' constitution to argue its position for today. Choosing to focus on the self-defense aspect of the Second Amendment, Scalia argued that "the inherent right of self-defense has been central to the Second Amendment right. The handgun ban amounts to a prohibition of an entire class of "arms" that is overwhelmingly chosen by American society for that lawful purpose” (Scalia, 128 S.Ct. at 2796). Scalia's context of judgement is a focus on the self defense aspect. By focusing on the intent and context behind the words, Scalia made the argument that handgun ownership is constitutional. However, Stevens' interpretation is quite different that Scalia's. Stevens has no official position: he is described as neither an originalist nor a pragmatist. Much like Scalia, Stevens utilizes a historical context in his argument. Stevens argues that the Second Amendment "protects only a right to possess and use firearms in connection with service in a state-organized militia" (Stevens, Dissenting, 128 S.Ct. at 2826). Stevens states that the Second Amendment limits the possession of a firearm for military purpose. Although both Stevens and Scalia agree that a well-regulated militia is important, Scalia explains that self-defense is the purpose of the Second Amendment while Stevens argues that the militia is the purpose of the Second Amendment. This dual reading of the Constitution is an example of semantic relativism: two radically different types of information are gained from a singular text. Specifically, their interpretation of different words such as "rights of the people," show the difference in their contexts of judgement. Their own understanding of the emphasis and meaning of the terms 
results in differing opinion. For example, Scalia says that the statement "refer to individual rights, not "collective" rights, or rights that may be exercised only through participation in some corporate body," while Stevens argues that the statement refers to "the collective action of individuals having a duty to serve in the militia that the text directly protects" (Scalia, $128 \mathrm{~S} . \mathrm{Ct}$ at 2796, Stevens, Dissenting, 128 S.Ct at 2826). Their interpretations of the term "rights of the people" allow for a different meaning and opinion of what the Constitution says. Semantic relativism enables them to each conduct a different interpretation of the Constitution.

In the specific case of the Supreme Court, two different interpretations can have a drastically different effect on the construction of societal norms. However, these interpretations stem from the same text. Each Justice focuses on the explicit words and ambiguity of the Second Amendment. Understanding the terms of agreement and disagreement can also allow us to view the consequences in a different light. Semantic relativism invites us to consider the multiple meanings of a statement. By studying semantic relativism, we can also view other opinions and decisions outside of majority rule, especially opinions that may otherwise be ignored. Semantic relativism contributes the context of judgement to the field of information science. By viewing others' arguments, we must re-evaluate our own - even if our position on the matter remains unchanged. This can help scholars of information science evaluate the ambiguity of information presented to them. To properly evaluate an argument, we must examine both sides. Semantic relativism is a nonbiased method of examining and explaining both sides of the argument. Although there are dangers, such as giving credibility to an unreliable source, this benefit far outweighs any drawback.

\section{Conclusion}


Although the contents of a text are relatively unchanging, the meanings behind its words can evolve over time. Semantic relativism can be utilized to analyze differences in these interpretations. By using District of Columbia v. Heller (2008) as a test case, I have demonstrated the usefulness of semantic relativism in the field of information science as a tool to understand differing points of view, especially in the case where each hold themselves to be true. Semantic relativism requires that we observe the context of judgement applied to all positions. This is a conceptual problem: by understanding the validity in each opinion, we can understand a more reconciliatory approach. More significantly, however, this exploration invites future research in revisiting previous information through the lens of semantic relativism. When paired with information literacy, which explores obtaining and evaluating resources, semantic relativism can focus on a unique way of evaluating and discussing information. Specifically, semantic relativism and the context of judgement ensure that other viewpoints are not only explored but respected as long as they have a basis in fact. In this way, semantic relativism's use as a lens presents new possibilities for scholarly work and information understanding. In an age of information, the most extreme perspectives are typically the loudest. However, there is more commonality than difference. By acknowledging that there is more than one legitimate position, semantic relativism allows us to read District of Columbia v. Heller (2008) and focus on the values presented by each justice. From this case study, we see that semantic relativism deserves further exploration and application in the field of library and information science. 


\section{References}

Baghramian, Maria and J. Adam Carter, "Relativism", The Stanford Encyclopedia of Philosophy (Fall 2020 Edition), Edward N. Zalta (ed.). URL: https://plato.stanford.edu/archives/fall2020/entries/relativism/

Barrett, A. C. (2016). Originalism and Stare Decisis. Notre Dame L. Rev., 92, 1921.

Berskyte, Justina \& Stevens, Graham. (2019). Semantic relativism, expressives, and derogatory epithets. Inquiry. 1-21. 10.1080/0020174X.2019.1612778.

Brodie M.L. (1984) On the Development of Data Models. In: Brodie M.L., Mylopoulos J., Schmidt J.W. (eds) On Conceptual Modelling. Topics in Information Systems. Springer, New York, NY. https://doi.org/10.1007/978-1-4612-5196-5_2

Calabresi, S., Beeman, R., Rubenstein, J., \& Siegel, R. (n.d.). On originalism in constitutional interpretation. Retrieved February 28, 2021, from https://constitutioncenter.org/interactive-constitution/white-papers/on-originalism-inconstitutional-interpretation

District of Columbia v. Heller, 554 US 570 (2008) (Scalia, A. majority).

District of Columbia v. Heller, 554 US 570 (2008) (Stevens, J. dissenting).

District of Columbia v. Heller. (n.d.). Oyez. Retrieved December 26, 2020, from https://www.oyez.org/cases/2007/07-290

Finkelman, P., \& Urofsky, M. I. (Eds.). (2002). A march of liberty: a constitutional history of the United States. From the founding to 1890. Oxford University.

Glanzberg, Michael. (2007). Context, Content, and Relativism. Philosophical Studies. 136. 1-29. 10.1007/s11098-007-9145-5.

Goldsworthy, J. (2000). Dworkin as an Originalist. Const. Comment., 17, 49.

Hobbs, Pamela. (2012). Not semantics but just results: The use of linguistic analysis in constitutional interpretation. Journal of Pragmatics. 44. 815-828. 10.1016/j.pragma.2012.03.001.

MacFarlane, John. (2007). Relativism and Disagreement. Philosophical Studies. 132. 17-31. 10.1007/s11098-006-9049-9.

McManus, M.A. (2019). Linguistic Meaning, Rigid Designators, and Legal Philosophy. Philosophies, 4, 15.

McMurray, Ash. (2019). Semantic Originalism, Moral Kinds, and the Meaning of the Constitution. BYU L. Rev. 695. https://digitalcommons.law.byu.edu/lawreview/vol2018/iss3/7 
Presser v. Illinois, 116 U.S. 252 (1886). (n.d.). Retrieved February 28, 2021, from https://supreme.justia.com/cases/federal/us/116/252

Rysiew, Patrick, "Epistemic Contextualism", The Stanford Encyclopedia of Philosophy (Spring 2021 Edition), Edward N. Zalta (ed.), forthcoming URL = <https://plato.stanford.edu/archives/spr2021/entries/contextualism-epistemology/>.

Solum, L. B. (2018). Originalism versus living constitutionalism: the conceptual structure of the great debate. Nw. UL Rev., 113, 1243.

Spaak, Torben. (2019). Relativism in the Philosophy of Law. 10.13140/RG.2.2.30450.76489.

Tarasov, L. (2020). Semantic Relativism and Logical Implication. Erkenntnis, 1-21.

U.S. Const. amend. II.

United States v. Miller, 307 U.S. 174 (1939). (n.d.). Oyez. Retrieved February 26, 2021, from https://supreme.justia.com/cases/federal/us/307/174/ 